\title{
Interactions between large high-severity fires and salvage logging on a short return interval reduce the regrowth of fire-prone serotinous forests
}

\author{
Angela Taboada ${ }^{\mathrm{a}, \mathrm{b}}$, , Víctor Fernández-García ${ }^{\mathrm{a}, \mathrm{b}}$, Elena Marcos ${ }^{\mathrm{a}, \mathrm{b}}$, Leonor Calvo ${ }^{\mathrm{a}, \mathrm{b}}$ \\ ${ }^{a}$ Area of Ecology, University of León, E-24071 León, Spain \\ ${ }^{\mathrm{b}}$ Institute of Environmental Research (IMA), University of Léon, E-24071 León, Spain
}

\section{A R T I C L E IN F O}

\section{Keywords:}

Disturbance interactions

Disturbance legacies

Ecosystem regeneration

Fire recurrence

Maritime pine

Post-fire restoration

\begin{abstract}
A B S T R A C T
New fire disturbance regimes under accelerating global environmental change can have unprecedented consequences for ecosystem resilience, lessening ecosystem natural regeneration. In the Mediterranean Basin, fire-dependent obligate seeder forests that are prone to increasingly frequent stand-replacing fires and then salvaged logged repeatedly can be vulnerable to additional disturbances for decades. In this study, we investigated, for the first time, the cumulative and interactive effects of two large high-severity fires at a short $(<15$-year) return interval and the subsequent burned timber harvesting with biomass removal on the post-disturbance recovery of such forests. We further assessed the type and amount of the material legacies (deadwood) that persisted through the different post-disturbance successional trajectories, as well as the influence of these legacies on forest regeneration. The early recovery of the studied forests after two consecutive large fires and post-fire logging was, in the first place, driven by fire repetition, which led to reduced seedling recruitment and enhanced regrowth of resprouter shrubs. Despite no interactive effects between fire and logging were detected after a single large fire event, two repeated fires followed by salvage harvesting had a greater negative impact than two fires alone (synergistic effects) on seedling establishment; while a lower positive impact (subadditive effects) on the recovery of resprouter shrubs. There was also an interaction modification effect in which fire repetition worsened the per-unit impact of salvage logging on forest regeneration. Nonetheless, the residual legacies, i.e., fine and coarse woody debris (unburned needles, downed branches, pieces of deadwood, and burned pine cones) that remained after the manual harvesting of the burned trees, aided seedling re-establishment and hindered the regrowth of the shrubby understorey. These findings indicate that high-intensity salvage logging after two large high-severity fires at a short return interval is inadvisable in fire-prone serotinous pine forests, unless it explicitly retains the key material legacies that help tree natural regeneration and enhance ecosystem resilience to the next disturbance.
\end{abstract}

\section{Introduction}

Disturbances are worldwide recognized as major drivers of ecosystem dynamics, influencing service provision and human wellbeing (Thom \& Seidl, 2016; Turner, 2010). Latest advances in disturbance ecology emphasize the complex nature and commonness of interactions involving both natural (e.g., wildfires, insect outbreaks, floods) and human (e.g., logging, grazing, sod-cutting) disturbances in many types of ecosystems (reviewed by Buma, 2015; Johnstone et al., 2016). Multiple disturbance interactions generally have unanticipated (sometimes counterintuitive) impacts on key ecosystem processes (Thom \& Seidl,
2016) that are unpredictable from knowledge of either disturbance alone (Buma, 2015; Doblas-Miranda et al., 2017) and critical to the management of ecosystems (Foster et al., 2016). This is particularly relevant in the Mediterranean Basin, a rich and unique biodiversity region with a long history of disturbances, but where knowledge on the ecological impacts of disturbance interactions remains scarce (Doblas-Miranda et al., 2014, 2017).

Rapid shifts in disturbance regimes (i.e., disturbance size, intensity, severity, and return interval; Turner, 2010) under accelerating global environmental change have further unprecedented consequences for ecosystem recovery and resilience to the next disturbance (Doblas-Miranda et al., 2017; Johnstone et al., 2016). These changes very

\footnotetext{
* Corresponding author at: Area of Ecology, Department of Biodiversity and Environmental Management, University of León, Campus Vegazana s/n, E-24071 León, Spain.

Email address: angela.taboada@unileon.es (A. Taboada)
} 
lead to novel combinations of disturbances (Lindenmayer, 2016), new post-disturbance successional trajectories (Trumbore et al., 2015; Turner, 2010) and altered disturbance legacies (Donato et al., 2016; Johnstone et al., 2016; Turetsky et al., 2017); which can trigger abrupt ecosystem transitions to alternate states (Johnstone et al., 2016) risking ecosystem collapse (Keith et al., 2013; Lindenmayer et al., 2016). For example, wildfires occur with greater frequency, extent and severity than in the past in Mediterranean ecosystems under a warmer and drier climate (Pausas \& Fernández-Muñoz, 2012; Pausas \& Vallejo, 1999; Pausas et al., 2008), promoting transitions to high-flammability shrublands (Baeza et al., 2007; González-De Vega et al., 2016; Retana et al., 2002) and challenging policy and landscape management (Moreira et al., 2011). Despite this, to our knowledge, there are no studies assessing the interactive effects and the potential cumulative impact ('double whammy' effect; Lindenmayer, 2016; Turner, 2010) of new wildfire regimes and post-fire management in Mediterranean ecosystems.

Large ( $>500$ ha) high-severity fires and post-fire salvage logging (i.e., the removal of burned trees and remaining woody debris) can interact via many different mechanistic pathways, basically divided into interaction chain and interaction modification effects (Didham et al., 2007; see also Foster et al., 2016). Fire can affect the likelihood of execution, and the nature and timing of post-fire logging (e.g., dependent on fire extent and severity), indirectly influencing harvest effects on ecosystem recovery (Fernández et al., 2008) (a chain interaction). Similarly, logging can affect the probability of occurrence and the magnitude of a subsequent fire by altering fuel and post-fire successional trajectories (Dunn \& Bailey, 2015; Fraver et al., 2011; Lindenmayer, 2016), also indirectly influencing fire effects on ecosystem recovery (a chain interaction). On the other hand, fire and post-fire logging can influence each other's impact on ecosystem regeneration, by altering e.g., plant species composition and response strategies (Blair et al., 2016; Calvo et al., 2012; Leverkus et al., 2014; Pausas et al., 2008), seedling recruitment and mortality (Castro et al., 2011; Espelta et al., 2008; Eugenio et al., 2006; Fernández et al., 2008), and the net outcome of plant interactions (Castro et al., 2011; Marañón-Jiménez et al., 2013; Marzano et al., 2013; Taboada et al., 2017) (an interaction modification). Disentangling the nature and relative importance of these interactions requires uncoupling their constituent legacies (Buma, 2015), and is crucial to develop novel management interventions to speed up ecosystem recovery under new disturbance scenarios (Didham et al., 2007; Foster et al., 2016; see e.g., Mandle \& Ticktin, 2012).

In this study, we analyse the interactions between and the potential cumulative effects of two sequential large high-severity fires and the subsequent salvage logging operations on the recovery of a Mediterranean fire-dependent obligate seeder forest (namely, serotinous maritime pine forest) threatened by increasing wildfire frequency (Bowman et al., 2014; Buma et al., 2013). We further examine the effects of the material legacies (deadwood) (Johnstone et al., 2016) that persisted through the different post-disturbance successional trajectories (i.e., recovery trajectories; Johnstone et al., 2016; Turner, 2010) on ecosystem regeneration. The regrowth of Mediterranean serotinous pine forests after a single fire is achieved by direct regeneration of the preceding plant community (associated to fire-stimulated seed germination and to the activation of resprouter species; Calvo et al., 2012; De las Heras et al., 2012; Pausas et al., 2008; Rodrigo et al., 2004). However, their recovery after a large high-severity fire that eliminates most of the vegetation can be undermined with prolonged deleterious effects (González-De Vega et al., 2016). We, therefore, expect that the occurrence of two consecutive large high-severity fires at a short return interval ( $<15$ years) will lessen forest regrowth as it will (i) lower the reproductive ability, recruitment and performance of serotinous pines (Espelta et al., 2008; Eugenio et al., 2006) and (ii) favour either fast- growing resprouter shrubs adapted to frequent fires (Calvo et al., 2012; Pausas \& Vallejo, 1999) or obligate seeder shrubs with fire-stimulated germination and tolerant to high-severity fires (Pausas \& Keeley 2014) and high water limitation (Moya et al., 2015).

We also expect a greater negative impact of a large high-severity fire on forest regrowth in combination with post-fire salvage logging (synergistic interactive effects); together with an interaction modification effect (Didham et al., 2007) in which (i) the per-unit impact of fire on forest recovery will be aggravated when harvesting is executed immediately ( $<1$ year) following fire (Fernández et al., 2008; Moya et al., 2015), and (ii) the per-unit effect of salvage logging will be worsened after two repeated fires at a short return interval. The disturbance caused by salvage logging operations (i.e., trampling, tree felling, and dragging) will damage the soil seed bank and increase soil compaction (Malvar et al., 2017) when removing potential nurse objects (burned tree trunks, branches, logs, and snags) that facilitate seedling establishment, overall reducing seedling recruitment and performance (Castro et al., 2011; Marañón-Jiménez et al., 2013). Moreover, salvage harvesting with biomass removal will strongly decrease or eliminate other fire-derived material legacies (particularly, fine and coarse woody residuals; Dunn \& Bailey, 2015; Hood et al., 2017; Keyser et al., 2009) that are important to seedling establishment (Marzano et al., 2013; Vacchiano et al., 2014), thus, negatively affecting forest regeneration (Lindenmayer \& Noss, 2006). We therefore expect a significant cumulative impact of repeated salvage logging after two consecutive large fires over relatively short time ( $<15$ years) on post-disturbance forest recovery (Lindenmayer, 2016).

\section{Materials and methods}

\subsection{Study area and fire history}

The study was conducted in Sierra del Teleno mountain range (NW Spain; $42^{\circ} 15^{\prime} 34^{\prime \prime} \mathrm{N} / 06^{\circ} 12^{\prime} 13^{\prime \prime} \mathrm{W}$; $915-1200 \mathrm{~m}$ a.s.1.; $10 \%$ average slope; Fig. 1), a landscape dominated by maritime pine (Pinus pinaster Ait.) natural forests (ca. 20,000 ha) for timber and resin production and with a tall (up to $1.5 \mathrm{~m}$ height) shrubby understorey [Erica australis L., Pterospartum tridentatum (L.) Willk., Halimium lasianthum spp. alyssoides (Lam.) Greuter]. The climate is Mediterranean with mean annual precipitation between $650-900 \mathrm{~mm}$, mean annual temperature of $10^{\circ} \mathrm{C}$, and 2-3 months of summer drought.

Wildfires are very frequent, typically caused by dry lightning storms [172 small fires (<500ha) in 1974-2007; Santamaría, 2015], and favoured by the coexistence of high plant productivity (fuel accumulation) and summer drought (Fernandes \& Rigolot, 2007). P. pinaster forests in the study area are highly adapted to intense crown fires with more than $95 \%$ of the trees bearing serotinous cones (Tapias et al., 2004). However, under the current fire return intervals (less than 10-15years; Santamaría, 2015) P. pinaster is frequently unable to reach reproductive maturity between repeated fires (Pausas et al., 2008; Tapias et al., 2001), and, therefore, at risk of disappearance in favour of shrublands, as in many areas of the western Mediterranean Basin (Baeza et al., 2007; Fernandes \& Rigolot, 2007).

In 1998, a large high-severity wildfire burned the area (13-14 September, 3670ha, pine tree density $=500-900$ individuals/ha, pine tree age $=60-85$ years-old) (Fig. 1). In 2012, a second large high-severity wildfire occurred (19-21 August, 9971 ha affected by a single large fire event, mean pine tree density $=906$ individuals/ha, pine tree age $=35-95$ years-old), partially overlapping the 1998 burn (1920 ha affected by the two large fire events, mean pine tree density $=12,778$ individuals/ha, pine tree age $=12-14$ years-old) (Fig. 1 ). Burn severity values ranged $2.25-3$ as measured directly in the field by the Compos- 

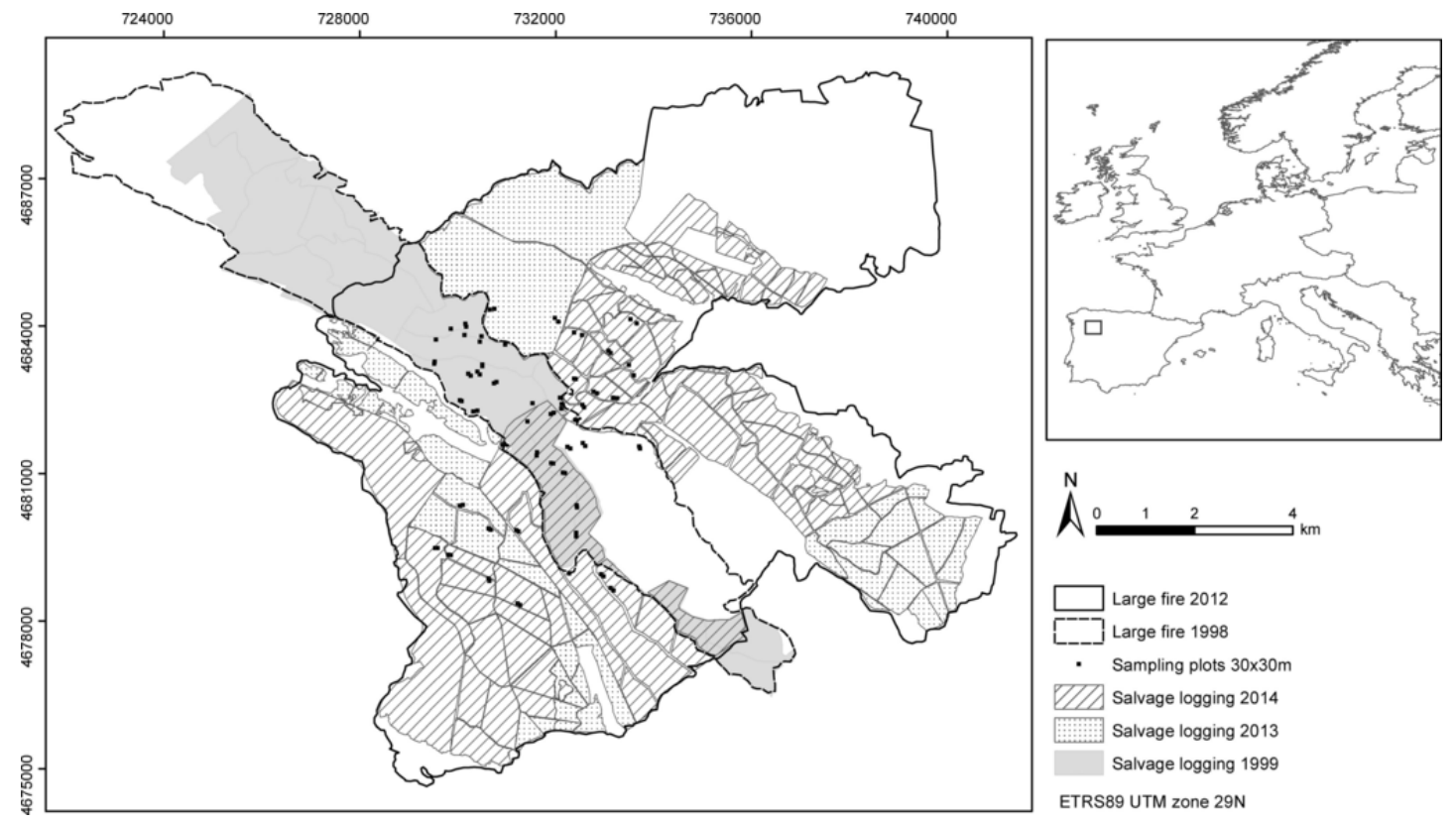

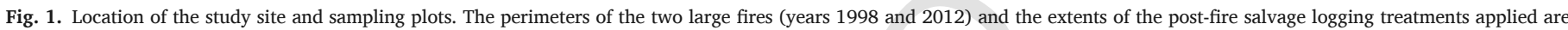
indicated. Light grey lines represent the limits of the forest stands harvested by the regional Forest Service.

ite Burn Index on a total of 111 30-m-diameter circular plots after the 2012 fire (Quintano et al., 2015, Quintano et al. (2017)). In both large fire events, the understorey was totally destroyed and the majority of tree crowns were completely consumed by fire. Subsequent to the two large fires, salvage logging of the burned stands was implemented by the regional Forest Service (Government of Castilla and León) with the same harvesting intensity (i.e., high intensity, with $70-80 \%$ of merchantable burned wood removed), either immediately following fire (<1 year; in 1999 and 2013, respectively) or after a short delay ( $>1$ year; in 2014) due to the vast extent of the burned area (Table 1).

Table 1

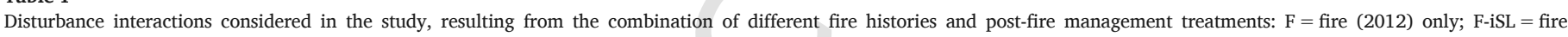

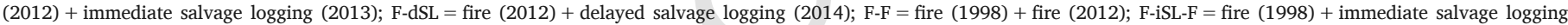

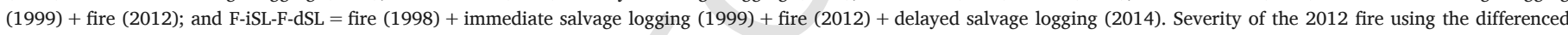

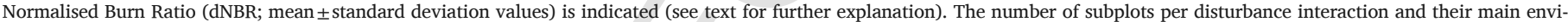
ronmental characteristics (mean \pm standard deviation values measured 33 months after the 2012 fire) are also indicated.

\begin{tabular}{|c|c|c|c|c|c|c|}
\hline & \multicolumn{6}{|c|}{ Disturbance interactions } \\
\hline & $\mathrm{F}$ & F-iSL & F-dSL & F-F & F-iSL-F & F-iSL-F-dSL \\
\hline $\begin{array}{l}\text { Large-fire } \\
\text { regime (year) }\end{array}$ & 1 fire (2012) & 1 fire (2012) & 1 fire (2012) & $\begin{array}{l}2 \text { fires (1998, } \\
2012)\end{array}$ & 2 fires $(1998,2012)$ & 2 fires $(1998,2012)$ \\
\hline $\begin{array}{l}\text { Fire severity } \\
\text { (dNBR) }\end{array}$ & $719.44 \pm 202.68$ & $993.45 \pm 54.91$ & $766.62 \pm 223.67$ & $953.51 \pm 96.74$ & $734.08 \pm 175.65$ & $864.09 \pm 125.40$ \\
\hline $\begin{array}{l}\text { Treatment } \\
\text { application } \\
\text { (year) }\end{array}$ & $\begin{array}{l}\text { Non- } \\
\text { intervention }\end{array}$ & $\begin{array}{l}\text { Immediate } \\
\text { salvage logging } \\
(2013)\end{array}$ & $\begin{array}{l}\text { Delayed salvage } \\
\text { logging (2014) }\end{array}$ & $\begin{array}{l}\text { Non- } \\
\text { intervention }\end{array}$ & $\begin{array}{l}\text { Non-intervention with } \\
\text { previous immediate } \\
\text { salvage logging (1999) }\end{array}$ & $\begin{array}{l}\text { Delayed salvage logging } \\
\text { (2014) with previous } \\
\text { immediate salvage } \\
\text { logging (1999) }\end{array}$ \\
\hline $\begin{array}{l}\text { Treatment } \\
\text { extent (ha) }\end{array}$ & & 2881 & 4318 & & 1744 & 597 \\
\hline $\begin{array}{l}\text { Number of } \\
\text { subplots }\end{array}$ & 12 & 18 & 96 & 18 & 54 & 36 \\
\hline Herbs (\%) & $2.88 \pm 6.01$ & $1.26 \pm 1.77$ & $2.78 \pm 5.82$ & $1.72 \pm 3.68$ & $0.67 \pm 1.17$ & $0.67 \pm 1.35$ \\
\hline $\begin{array}{l}\text { Halimium } \\
\text { lasianthum } \\
(\%)\end{array}$ & $16.31 \pm 13.94$ & $16.63 \pm 12.72$ & $18.30 \pm 11.40$ & $17.19 \pm 11.00$ & $12.69 \pm 8.69$ & $11.99 \pm 7.09$ \\
\hline $\begin{array}{l}\text { Erica australis } \\
(\%)\end{array}$ & $4.06 \pm 6.62$ & $6.26 \pm 9.81$ & $6.70 \pm 8.87$ & $16.24 \pm 11.83$ & $12.24 \pm 12.56$ & $15.76 \pm 14.16$ \\
\hline $\begin{array}{l}\text { Pterospartum } \\
\text { tridentatum } \\
(\%)\end{array}$ & $8.21 \pm 8.72$ & $9.18 \pm 8.74$ & $10.49 \pm 9.96$ & $33.17 \pm 15.14$ & $16.87 \pm 8.76$ & $23.76 \pm 14.39$ \\
\hline $\begin{array}{l}\text { Fine woody } \\
\text { debris (\%) }\end{array}$ & $18.58 \pm 11.29$ & $8.90 \pm 12.51$ & $12.77 \pm 12.76$ & $7.10 \pm 16.30$ & $1.74 \pm 2.77$ & $0.81 \pm 1.82$ \\
\hline $\begin{array}{l}\text { Coarse woody } \\
\text { debris }(\%)\end{array}$ & $15.21 \pm 14.76$ & $12.19 \pm 4.77$ & $11.76 \pm 10.38$ & $5.49 \pm 4.22$ & $2.97 \pm 3.83$ & $3.83 \pm 5.05$ \\
\hline $\begin{array}{l}\text { Standing dead } \\
\text { trees (\%) }\end{array}$ & $0.00 \pm 0.00$ & $0.14 \pm 0.40$ & $0.04 \pm 0.24$ & $2.03 \pm 2.43$ & $1.31 \pm 1.64$ & $2.92 \pm 2.81$ \\
\hline
\end{tabular}


In the salvaged stands, all dead trees were cut and felled by mechanical chain saws, trunks were manually dragged and piled at firebreaks and roads, branches and woody debris were chopped, and all the cut biomass was extracted for timber or fuel production (see Taboada et al., 2017 for additional information). Only unprofitable burned trees ( $<10 \mathrm{~cm}$ diameter) were left onsite. In total, after the 1998 and 2012 fires, more than 150,000 and $476,000 \mathrm{~m}^{3}$ of burned wood were sold with a commercial value of ca. 1,423,000 and 2,553,000 $€$, respectively (Government of Castilla and León, personal communication). Total annual precipitation in the years of salvage logging was comparatively low [324.1 and $323.2 \mathrm{~mm}$ in 2013 and 2014, respectively: weather station Lagunas de Somoza, Spanish Meteorological Agency (AEMET)], possibly affecting post-fire pine tree regeneration (Alfaro-Sánchez et al., 2015).

\subsection{Sampling design and field measurements}

We considered the following disturbance interactions (Fig. 2):

(1) fire (2012) only (' $F$ ');

(2) fire (2012) + immediate salvage logging (2013) ('F-iSL');

(3) fire (2012) + delayed salvage logging (2014) ('F-dSL');

(4) fire (1998) + fire (2012) ('F-F');

(5) fire (1998) + immediate salvage logging (1999) + fire (2012) ('F-iSL-F');

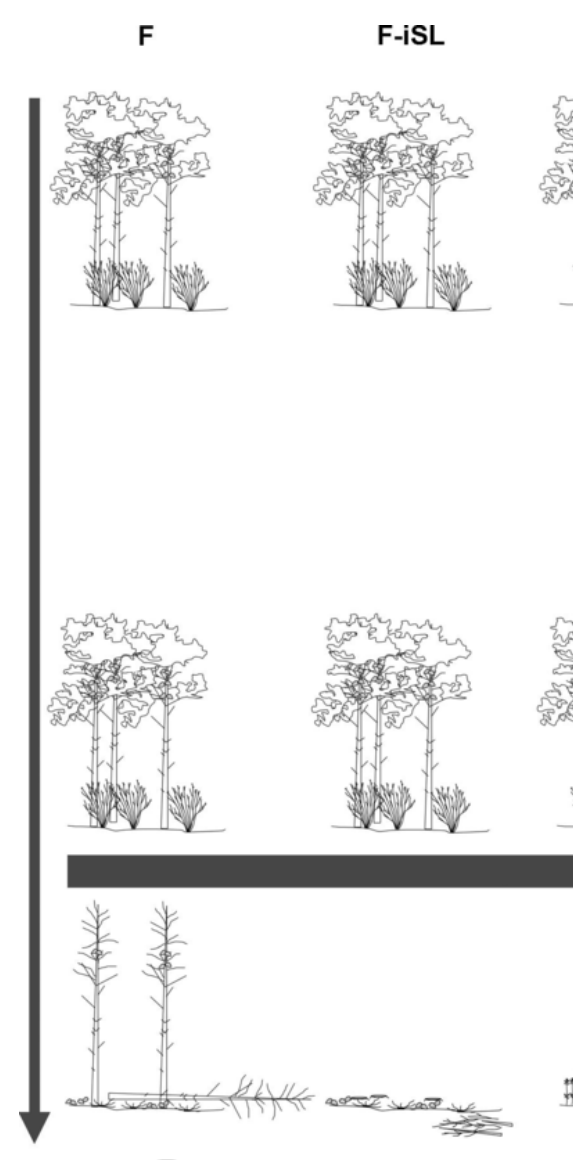

F-dSL
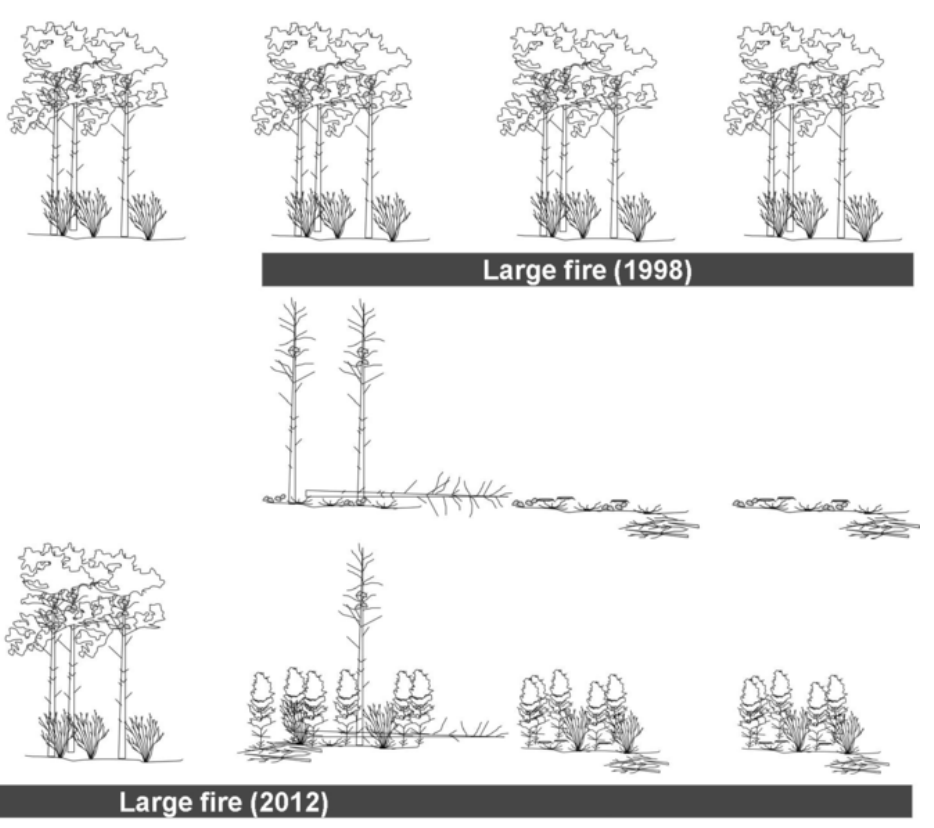

Large fire (2012)
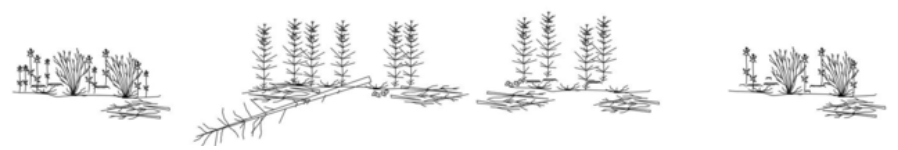

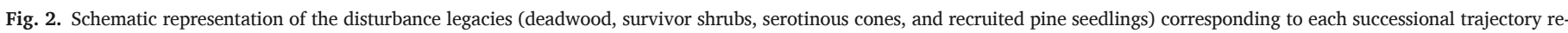

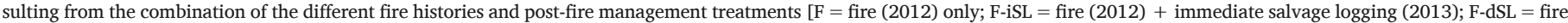

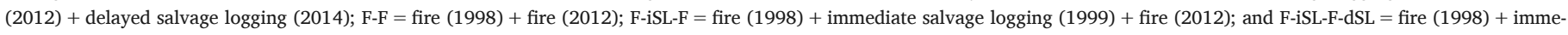
diate salvage logging (1999) + fire (2012) + delayed salvage logging (2014)]. 
quadrats). Seedling mortality was insignificant at these stages of succession, as the number of dead seedlings in the $2342 \mathrm{~m} \times 2 \mathrm{~m}$ surveyed subplots was low (mean \pm standard deviation $=0.61 \pm 2.33$ ). To assess the post-disturbance regrowth of the shrubby understorey, in each subplot we measured the mean percentage cover of all woody species (average value of the four quadrats). We classified these species according to their post-fire recovery strategies (Paula et al., 2009) into obligate seeder species [H. lasianthum spp. alyssoides, Erica umbellata Loefl. ex L., H. umbellatum (L.) Spach, Calluna vulgaris (L.) Hull, Cistus salviifolius (L.)] and resprouter species (E. australis, P. tridentatum, E. arborea L., Polygala microphylla L.), and calculated the mean percentage cover of each life-form group per subplot. To characterise the material legacies (deadwood) resulting from the six combinations of fire history and post-fire salvage logging (i.e., from the different post-disturbance successional trajectories; Fig. 2), in each subplot we quantified the mean percentage cover (average value of the four quadrats) of (1) fine woody debris (downed branches and pieces of deadwood $<2 \mathrm{~cm}$ diameter, and remaining unburned foliage), (2) coarse woody debris (downed branches and pieces of deadwood $>2 \mathrm{~cm}$ diameter, fallen dead trees $<10 \mathrm{~cm}$, burned pine cones, and post-harvest stumps), and (3) standing dead trees (burned trees left onsite after harvesting operations or non-intervention).

\subsection{Data analysis}

We fitted generalised linear mixed models (GLMMs) to assess the effects of the six combinations of fire history and post-fire salvage logging on (1) the number of pine seedlings alive, (2) the percentage cover of pine seedlings, (3) the percentage cover of obligate seeder species, and (4) the percentage cover of resprouter species. The response variables were modelled following a quasi-Poisson error distribution, using the log link function, to account for overdispersion. We also fitted a linear mixed model (LMM) to test the effects of the six combinations of fire history and post-fire salvage logging on (5) pine seedling height, modelled assuming a Gaussian error distribution (identity link function). The predictor variables (fixed factors) in the models were fire severity (dNBR) and the type of disturbance interaction (F, F-iSL, F-dSL, F-F, F-iSL-F, and F-iSL-F-dSL). The identity of the sampling plots was included as a random factor into the models. We ob- tained predicted values of the response variables from the models for the mean value of fire severity $(\mathrm{dNBR}=793.33)$ and each type of disturbance interaction.

We performed analogous GLMMs and LMM to determine the influence of the disturbance legacies (deadwood) on the above mentioned five response variables. The predictor variables in the models were the percentage cover of fine woody debris, coarse woody debris and standing dead trees. For the three pine models (seedling number, percentage cover and height), we additionally included as predictors into the models the percentage cover of $H$. lasianthum, E. australis, and P. tridentatum, to account for potential competitive interactions between pine seedlings and shrubs that might result in higher seedling height and lower seedling aerial biomass (Taboada et al., 2017). The identity of the sampling plots was included as a random factor into the models.

All data analyses were carried out with $\mathrm{R}$ software, version 3.3.1 ( $\mathrm{R}$ Core Team, 2016) using the 'stats', 'ImerTest' (Kuznetsova et al., 2016), 'nlme' (Pinheiro et al., 2016) and 'MASS' (Venables \& Ripley, 2002) packages.

\section{Results}

\subsection{Pine tree regeneration}

Fire history and post-fire salvage logging had significant effects on pine seedling recruitment and performance (Table 2, Fig. 3). The estimated effects (model coefficients) of two subsequent fires on pine tree regeneration at early successional stages were always negative, and were exacerbated by the application of post-fire salvage logging. Both the total number of seedlings alive and the mean seedling height were significantly lower in the F-iSL-F and F-iSL-F-dSL plots; whereas the average seedling cover was significantly lower in the F-F, F-iSL-F and F-iSL-F-dSL plots. Fire severity (dNBR) had significantly negative effects only on the number of pine seedlings alive.

The material legacies (deadwood) resulting from the different disturbance interactions significantly influenced the regeneration of pine trees in the early stages of succession (Table 3). The estimated effects of fine and coarse woody debris, and standing dead trees on seedling recruitment and growth were predominantly positive. The existence of fine woody debris significantly enhanced the total number of seedlings

Table 2

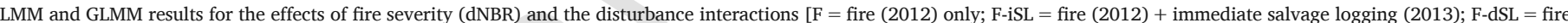

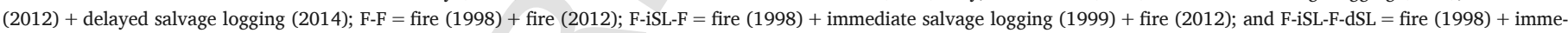

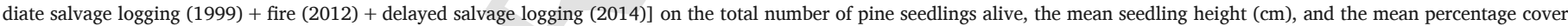
(\%) of seedlings, obligate seeder and resprouter shrub species. The intercept represents the factor level F. SE $=$ standard error. Significant p-values are in bold face.

\begin{tabular}{|c|c|c|c|c|c|c|c|c|}
\hline & & Intercept & dNBR & F-iSL & F-dSL & F-F & F-iSL-F & F-iSL-F-dSL \\
\hline \multirow[t]{3}{*}{ Number of pine seedlings } & Estimate & 3.334 & -0.000 & 0.046 & -0.197 & -0.969 & -2.497 & -2.165 \\
\hline & $\mathrm{SE}$ & 0.515 & 0.000 & 0.549 & 0.443 & 0.583 & 0.542 & 0.573 \\
\hline & p-value & $<0.001$ & 0.022 & 0.933 & 0.658 & 0.101 & $<0.001$ & $<0.001$ \\
\hline \multirow[t]{3}{*}{ Pine seedling height $(\mathrm{cm})$} & Estimate & 21.511 & 0.006 & 0.139 & -6.653 & -5.972 & -21.056 & -12.200 \\
\hline & & 6.526 & 0.006 & 6.602 & 5.344 & 6.568 & 5.568 & 5.843 \\
\hline & p-value & 0.001 & 0.327 & 0.983 & 0.217 & 0.366 & $<0.001$ & 0.040 \\
\hline \multirow[t]{3}{*}{ Pine seedling cover (\%) } & Estimate & 2.470 & -0.000 & 0.055 & -0.592 & -1.284 & -2.881 & -2.114 \\
\hline & SE & 0.477 & 0.000 & 0.476 & 0.387 & 0.516 & 0.497 & 0.485 \\
\hline & p-value & $<0.001$ & 0.383 & 0.908 & 0.130 & 0.015 & $<0.001$ & $<0.001$ \\
\hline \multirow[t]{3}{*}{ Seeder shrubs cover $(\%)$} & Estimate & 3.047 & -0.000 & 0.115 & 0.297 & 0.113 & 0.065 & -0.084 \\
\hline & SE & 0.258 & 0.000 & 0.262 & 0.211 & 0.260 & 0.221 & 0.236 \\
\hline & p-value & $<0.001$ & 0.135 & 0.661 & 0.163 & 0.664 & 0.770 & 0.723 \\
\hline \multirow[t]{3}{*}{ Resprouter shrubs cover (\%) } & Estimate & 2.252 & 0.000 & 0.089 & 0.255 & 1.351 & 0.850 & 1.133 \\
\hline & SE & 0.346 & 0.000 & 0.372 & 0.304 & 0.348 & 0.311 & 0.320 \\
\hline & $\mathrm{p}$-value & $<0.001$ & 0.213 & 0.812 & 0.404 & $<0.001$ & 0.008 & $<0.001$ \\
\hline
\end{tabular}



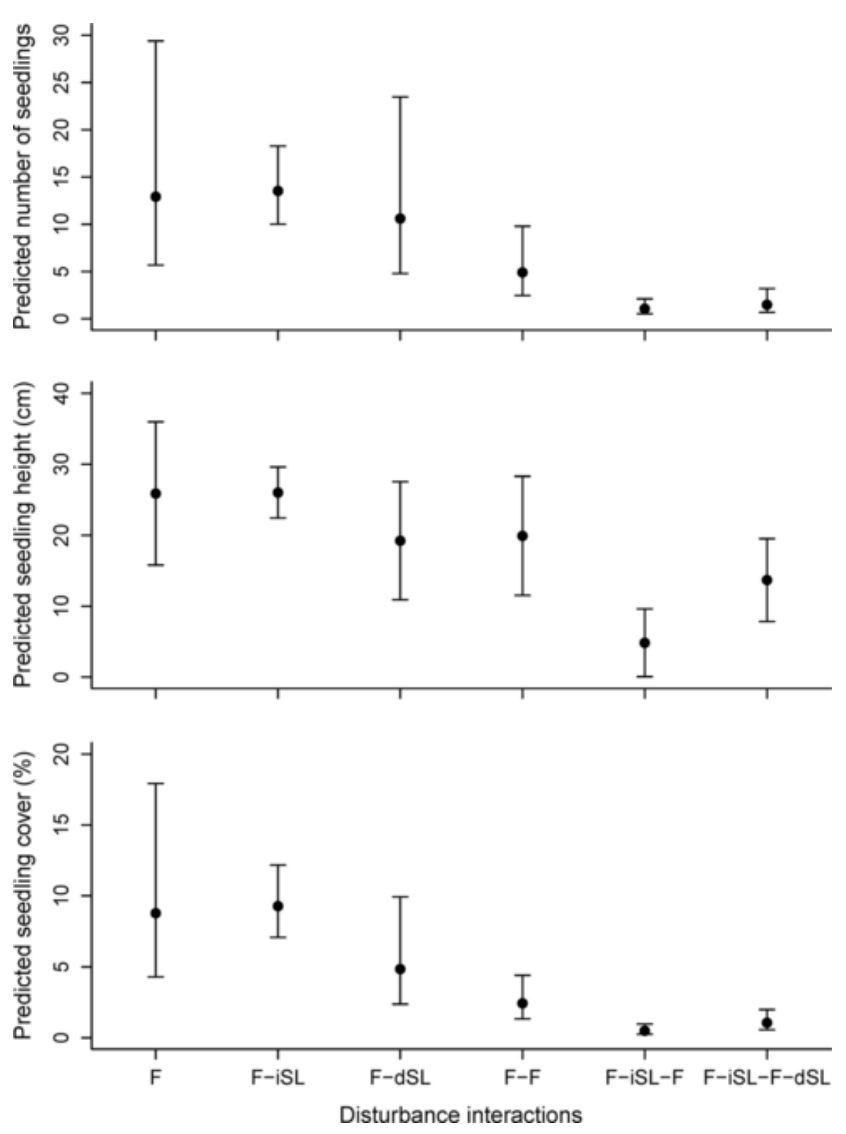

Fig. 3. Model predicted values (mean $\pm 95 \%$ confidence intervals) of the total number of pine seedlings alive per $2 \mathrm{~m} \times 2 \mathrm{~m}$ subplot, the mean seedling height $(\mathrm{cm})$ and percentage cover $(\%)$ in each disturbance interaction $[\mathrm{F}=$ fire $(2012)$ only; F-iSL $=$ fire (2012) + immediate salvage logging (2013); F-dSL = fire (2012) + delayed salvage logging (2014); F-F = fire (1998) + fire (2012); F-iSL-F = fire (1998) + immediate salvage logging (1999) + fire (2012); and F-iSL-F-dSL = fire (1998) + immediate salvage logging (1999) + fire (2012) + delayed salvage logging (2014)]

alive, the mean seedling height and cover. While the presence of coarse woody debris and standing dead trees significantly benefited the mean seedling height.

The recovery of the main shrub species in the understorey negatively affected initial pine tree regeneration (i.e., for the most part, the model coefficients were negative) (Table 3 ). All three shrub species tested (H. lasianthum, $E$. australis, and $P$. tridentatum) significantly negatively impacted pine seedling cover (proxy for aerial biomass); whereas only $E$. australis had a significant negative effect on the number of pine seedlings alive.

\subsection{Understorey regrowth}

The mean percentage cover of obligate seeder species was not affected by the different combinations of fire history and post-fire salvage logging (Table 2, Fig. 4). However, in case of the mean percentage cover of resprouter species, the estimated effects of two subsequent fires were significantly positive (higher values in the F-F, F-iSL-F and F-iSL-F-dSL plots) especially in the absence of harvesting operations following fire (F-F plots).

The material legacies (deadwood) resulting from the different disturbance interactions significantly affected the regrowth of the shrubby understorey (Table 3). The mean percentage cover of obligate seeder species was significantly negatively related to coarse woody debris; whereas the mean percentage cover of resprouter species was significantly negatively related to both fine and coarse woody debris. Re- sprouter species were, however, significantly favoured by the presence of standing dead trees.

\section{Discussion}

\subsection{Cumulative and interactive effects of fire and salvage logging}

Upcoming changes in wildfire regimes with even more frequent fires, shorter fire-free periods, larger fire spatial extents, and higher fire severities (Pausas \& Fernández-Muñoz, 2012; Pausas \& Vallejo, 1999; Pausas et al., 2008) are expected to weaken the post-fire regeneration and, eventually, the resilience of serotinous species and ecosystems globally (Bowman et al., 2014; Brown \& Johnstone, 2012; Buma et al., 2013). In the studied stands the cumulative impact of two large fires occurring in the same location at a short return interval ( $<15$ years) (F vs. F-F) lessened serotinous pine seedling recruitment and performance, and enhanced the regrowth of resprouter shrubs, in agreement with previous studies (e.g., Calvo et al., 2012; Espelta et al., 2008; Eugenio et al., 2006; Pausas \& Vallejo, 1999). Pine seedling cover (a proxy for aerial biomass) was particularly reduced by fire repetition, while there were no differences for seedling height, possibly denoting competition for belowground resources (i.e., water and nutrients) with pioneer shrubs (Calvo et al., 2008; Taboada et al., 2017). These findings confirmed the ('double whammy') effect of two consecutive large fires occurring in relatively short time (see Turner, 2010), as the serotinous pine forest ecosystem had not yet recovered from the disturbance created by the first fire when affected by the second one, facing an immaturity risk (sensu Keeley et al., 1999). Above all, the pre-fire state (before the 2012 fire; Fig. 2) of the stands that suffered one or two large fires conditioned their post-disturbance recovery. Once-burned plots had (1) low density of mature pines with high reproductive ability attained during the previous fire-free interval (>15years; Tapias et al., 2004), (2) few shrubs in the understorey, and, therefore, (3) greater pine seedling regeneration. While twice-burned plots had (1) high density of immature pines with low reproductive ability (i.e., small canopy seed bank; Espelta et al., 2008), (2) a well-developed shrub layer, and, thus, (3) greater regrowth of the understorey. In addition, no differences between once- and twice-burned plots were observed for the recovery of obligate seeder shrubs that are tolerant to high-severity fires and variable water conditions (Moya et al., 2015), and slowly regenerated from their persistent soil seed banks (Pausas \& Keeley, 2014).

Unexpectedly, there were no interactive (synergistic) effects between fire and salvage logging after a single large high-severity fire ( $F$ vs. F-iSL and F-dSL), as the removal of the burned wood did not decrease pine seedling recruitment and performance more than did fire alone. Particularly, in the studied stands, immediate $(<1$ year after fire) salvage logging had no detrimental effects on the natural regeneration of the vegetation; contrarily to previous results by other authors that demonstrated the negative impact of harvesting operations on pine seedling emergence and mortality, plant species composition and diversity, shrub regrowth, and plant facilitative interactions (e.g., Castro et al., 2011; Leverkus et al., 2014; Lindenmayer \& Noss, 2006; Marañón-Jiménez et al., 2013; Moya et al., 2015). Firstly, the high number of mature trees bearing serotinous cones in the studied maritime pine population (Tapias et al., 2004) very likely resulted in a large number of recruited seedlings (Calvo et al., 2008; Hernández-Serrano et al., 2013) that were either very abundant to counterbalance mortality (Martínez-Sánchez et al., 1999) or not seriously damaged by the prompt harvesting operations, as trunks were manually handled without heavy machinery (see Blair et al., 2016; Castro et al., 2011; Leverkus et al., 2014, and references therein). Secondly, the removal of the burned wood avoiding mechanical disturbance may have caused relatively little damage besides that of fire to (1) the persistent soil 
Table 3

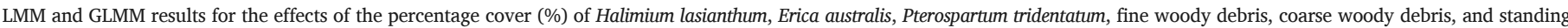

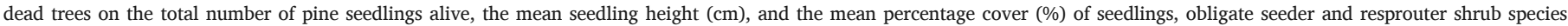
$\mathrm{SE}=$ standard error. Significant $\mathrm{p}$-values are in bold face.

\begin{tabular}{|c|c|c|c|c|c|c|c|c|}
\hline & & Intercept & $\begin{array}{l}\mathrm{H} . \\
\text { lasianthum }\end{array}$ & $\begin{array}{l}\text { E. } \\
\text { australis }\end{array}$ & $\begin{array}{l}P . \\
\text { tridentatum }\end{array}$ & $\begin{array}{l}\text { Fine woody } \\
\text { debris }\end{array}$ & $\begin{array}{l}\text { Coarse woody } \\
\text { debris }\end{array}$ & $\begin{array}{l}\text { Standing dead } \\
\text { trees }\end{array}$ \\
\hline \multirow{3}{*}{$\begin{array}{l}\text { Number of pine } \\
\text { seedlings }\end{array}$} & Estimate & 2.015 & -0.002 & -0.026 & -0.013 & 0.020 & 0.002 & -0.055 \\
\hline & SE & 0.259 & 0.006 & 0.010 & 0.007 & 0.006 & 0.007 & 0.072 \\
\hline & p-value & $<0.001$ & 0.680 & 0.009 & 0.087 & 0.002 & 0.756 & 0.449 \\
\hline \multirow{3}{*}{$\begin{array}{l}\text { Pine seedling } \\
\text { height }(\mathrm{cm})\end{array}$} & Estimate & 11.456 & 0.009 & -0.053 & -0.060 & 0.274 & 0.250 & 1.697 \\
\hline & SE & 3.315 & 0.090 & 0.098 & 0.089 & 0.097 & 0.118 & 0.566 \\
\hline & p-value & 0.001 & 0.920 & 0.589 & 0.503 & 0.005 & 0.035 & 0.003 \\
\hline \multirow{3}{*}{$\begin{array}{l}\text { Pine seedling cover } \\
(\%)\end{array}$} & Estimate & 1.628 & -0.012 & -0.031 & -0.023 & 0.013 & 0.002 & 0.057 \\
\hline & SE & 0.245 & 0.006 & 0.009 & 0.007 & 0.006 & 0.007 & 0.052 \\
\hline & p-value & $<0.001$ & 0.038 & 0.001 & 0.002 & 0.037 & 0.737 & 0.274 \\
\hline \multirow{3}{*}{$\begin{array}{l}\text { Seeder shrubs cover } \\
(\%)\end{array}$} & Estimate & 3.090 & & & & 0.000 & -0.015 & -0.047 \\
\hline & SE & 0.074 & & & & 0.004 & 0.005 & 0.026 \\
\hline & p-value & $<0.001$ & & & & 0.986 & 0.004 & 0.070 \\
\hline \multirow{3}{*}{$\begin{array}{l}\text { Resprouter shrubs } \\
\text { cover }(\%)\end{array}$} & Estimate & 3.403 & & & & -0.015 & -0.031 & 0.042 \\
\hline & SE & 0.084 & & & & 0.005 & 0.006 & 0.018 \\
\hline & $\mathrm{p}$-value & $<0.001$ & & & & 0.001 & $<0.001$ & 0.024 \\
\hline
\end{tabular}
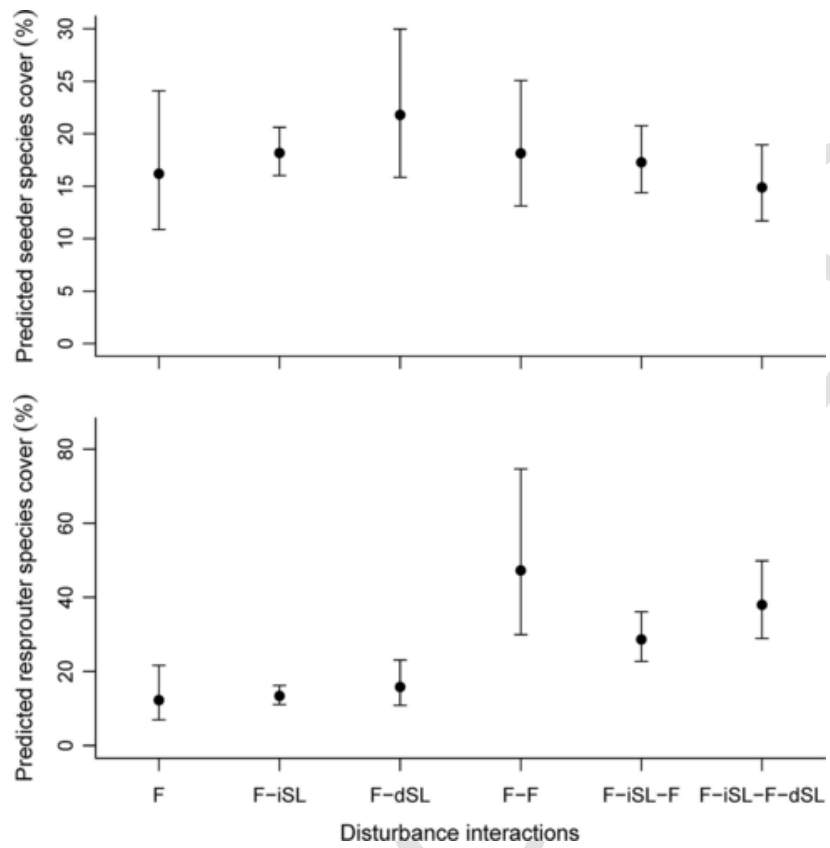

Fig. 4. Model predicted values (mean $\pm 95 \%$ confidence intervals) of the mean percentage cover (\%) of obligate seeder and resprouter shrub species in each disturbance interaction [F = fire (2012) only; F-iSL = fire (2012) + immediate salvage logging (2013); $\mathrm{F}-\mathrm{dSL}=$ fire $(2012)+$ delayed salvage logging (2014); F-F = fire $(1998)+$ fire (2012); F-iSL-F $=$ fire (1998) + immediate salvage logging (1999) + fire (2012); and F-iSL-F-dSL $=$ fire (1998) + immediate salvage logging (1999) + fire (2012) + delayed salvage logging (2014)]. Obligate seeder species: Halimium lasianthum spp. alyssoides, Erica umbellata, H. umbellatum, Calluna vulgaris, and Cistus salviifolius. Resprouter species: E. australis, Pterospartum tridentatum, E. arborea, and Polygala microphylla.

seed bank and the newly emerged seedlings of obligate seeder shrubs, as well as to (2) the new shoots produced by resprouter shrubs (Knapp \& Ritchie, 2016; Leverkus et al., 2014).
The interactive effects of fire and salvage logging on post-disturbance forest regrowth were more evident after two consecutive fires at a short return interval (F-F vs. F-iSL-F). Two successive large fires combined with post-fire logging had a greater negative impact than fires alone (synergistic effects) on the number of recruited pine seedlings, seedling height and cover; while a lower positive impact (subadditive effects) on the recovery of resprouter shrub species. However, repeated salvage logging following each of the two consecutive large fires had no greater negative impact on forest regrowth than the two high-severity fires at a short return interval (F-F vs. F-iSL-F-dSL); but it had a comparable negative impact to salvage harvesting on one occasion combined with two large fire events (F-iSL-F vs. F-iSL-F-dSL). This suggests that the natural regeneration of the studied serotinous pine forests subjected to two short-return-interval large fires was undermined by the salvage harvesting of the merchantable burned wood regardless if executed one single time (i.e., after the first large fire event) or as many times as fire occurred (i.e., after every sequential large fire event).

\subsection{Interaction modification effects of fire and salvage logging}

In addition, our results evidenced that the per-unit impact of a single large stand-replacing fire on forest recovery did not depend on the timing of post-fire salvage logging, as fire impact was only marginally aggravated when harvesting was executed more than one year after fire (i.e., no interaction modification effect; Didham et al., 2007) (F-iSL vs. F-dSL). Nonetheless, in the studied serotinous pine stands, the impact of salvage logging on forest re-establishment was worsened in combination with two recurrent fires happening at a short return interval (F-iSL vs. F-iSL-F). This can be considered an interaction modification effect (Didham et al., 2007), in which the per-unit effect of salvage logging depends on the frequency of occurrence of the sequential large fires in the same location and, most likely, on the duration of the fire-free interval. This, again, supports the idea that high-intensity salvage harvesting after two recurrent large high-severity fires may be inadvisable in fire-prone serotinous pine forests, given that it hindered the al- 
ready lessened pine seedling recruitment and performance, unless additional management interventions can be implemented to counterbalance these effects (Lindenmayer et al., 2017). These findings are highly relevant to the restoration management of serotinous pine forests under increasing uncertainty (De las Heras et al., 2012; Doblas-Miranda et al., 2014, 2017; see also Lindenmayer, 2016), as the new combinations of frequent wildfires and salvage logging may cause major irreversible (or very difficult or costly to reverse) changes in the ecosystem's resilience to the next disturbance (Buma \& Wessman, 2011; Lindenmayer et al., 2016; see also Mandle et al., 2015).

\subsection{The importance of the material legacies that persisted after disturbance}

Both the pre-disturbance state of an ecosystem and the characteristics of the disturbance regime determine the type and amount of the biologically derived legacies that persist following a series of successive disturbance events (Johnstone et al., 2016). In the studied pine forest stands, three major factors may have influenced how much needle litter and woody debris accumulated before disturbance (fire and logging), and how many legacies (deadwood) remained after that (Fig. 2): (1) the age and degree of development of the pine trees and the shrubby understory attained in the preceding fire-free interval, (2) the degree of consumption of the litter layer and woody debris after one or two high-severity fires, and (3) the volume of burned wood and harvest slash removed by the sequential high-intensity salvage logging operations after fire.

As the 2012 large fire mostly consumed the organic layer and surface needles exposing the mineral soil, as well as the majority of the standing biomass and canopy leaves (see Quintano et al., 2015; Quintano et al., 2017), the retained deadwood after disturbance was mostly in the form of stumps and logging residues. Our results indicated that the amount of harvest slash (fine and coarse woody debris) left by the manual extraction of the merchantable burned trees after a single large high-severity fire (F-iSL and F-dSL; Table 1 ) was greater than anticipated on the basis of prior researches (Dunn \& Bailey, 2015; Hood et al., 2017; Keyser et al., 2009), and benefited pine seedling emergence and performance. The remaining fine woody debris enhanced the number of recruited pine seedlings and seedling growth (height and percentage cover), very likely by (1) providing seed protection from predation and adverse climate (Madrigal et al., 2005; Rodríguez et al., 2008; Rodríguez-García et al., 2010), and (2) increasing moisture and nutrients that helped seed germination and seedling establishment (particularly, the unburned pine needles fallen from a small number of scorched trees prior to removal) (Marañón-Jiménez \& Castro, 2013; Marañón-Jiménez et al., 2013; Marzano et al., 2013; Vacchiano et al., 2014). Whereas the residual coarse woody debris may have increased pine seedling height via facilitative interactions by the downed branches and fallen immature dead trees left in place, eluding belowground plant competition (Castro et al., 2011; Marañón-Jiménez et al., 2013; Marzano et al., 2013). Moreover, although salvage logging removed cone-bearing branches along with the trunks, many loose burned serotinous cones were left onsite and gradually released viable seeds (up to five years after fire; personal observations) helping the post-disturbance establishment of pine seedlings, similar to the findings of Calvo et al. (2013) and Fernández et al. (2008).

However, the removal of the burned wood combined with the occurrence of two consecutive large fires at a short return interval (F-iSL-F and F-iSL-F-dSL) substantially reduced the quantity of residual fine and coarse woody debris (Table 1); while it very much increased the number of immature (unprofitable) standing dead trees left onsite. Altogether, the little woody debris and the abundant standing dead trees in the twice-burned plots mostly benefited the regrowth of resprouter shrubs. All in all, these findings indicate that logging after a first large fire event very likely affected the material legacies required for the ecosystem re-establishment following a second large fire (Donato et al., 2016); pointing out an unforeseen interaction modification effect (Didham et al., 2007) in which the per-unit impact of a successive fire depends on the type and amount of deadwood retained by the harvesting operations after a preceding fire. This implies that special care should be taken when high-intensity salvage logging is executed in areas that are prone to frequent high-severity fires in order to prevent the unnecessary removal of the residual biomass produced by the single disturbance events (see D'Amato et al., 2011; Lindenmayer et al., 2017). These material legacies will eventually contribute to enhance the resilience of serotinous pine forests to novel disturbances in the future (Johnstone et al., 2016).

\section{Conclusions}

Serotinous pine forests coping with frequent large stand-replacing fires at short return intervals are of particular preservation concern (Bowman et al., 2014; Buma et al., 2013), as these fires cause high tree mortality, incapacity to reach maturity and, ultimately, the failure of natural tree regeneration (Espelta et al., 2008; Eugenio et al., 2006; Fernandes \& Rigolot, 2007). In our study, the initial recovery of the surveyed serotinous maritime pine forests after two sequential large fires and post-fire logging was, in the first place, driven by fire repetition, which led to reduced seedling recruitment and enhanced regrowth of resprouter shrubs. In the second place, high-intensity post-fire salvage logging worsened the impact of fire on pine forest regeneration only when implemented after two repeated large high-severity fires. Therefore, it is very likely that, without appropriate mitigating measures, the resilience of these fire-prone serotinous forests to future disturbances will be jeopardised by the interactive effects of sequential large high-severity fires and successive post-fire logging.

But our findings further demonstrated that the initial recovery of the studied serotinous forests was greatly affected by the nature and quantity of the material legacies (deadwood) resulting from the different disturbance histories. Retained fire-killed trees and post-harvest residuals were the legacies that primarily influenced pine seedling re-establishment, in accordance with the results of previous studies (Marzano et al., 2013; Vacchiano et al., 2014). Preserving a considerable amount of fine and coarse woody debris (i.e., unburned needles, downed branches, pieces of deadwood, and burned pine cones) in situ after the manual harvesting of the merchantable burned trees, improved pine seedling performance and limited the regrowth of the shrubby understorey. This implies that carefully designed salvage logging interventions with partial biomass retention after successive large fires may constitute a suitable alternative for limiting (or even counteracting) the harmful effects of the increased fire frequency on the early recruitment and natural regeneration of maritime pine forests (see Lindenmayer et al., 2017). This, then, opens the possibility of integrating fire- and logging-derived legacies in specific ('more ecologically sensitive'; Hunter, 2007) post-fire restoration actions to enhance the resilience of these serotinous forests to the new combinations of large-scale disturbances that are unpredictable (Johnstone et al., 2016).

\section{Acknowledgements}

We thank the Environmental Department of the Regional Government of Castilla and León for the information provided. The study was financed by the Spanish Ministry of Economy and Competitiveness (GESFIRE project, AGL2013-48189-C2-1-R), the Regional Government of Castilla and León (FIRECYL project, LE033U14), and the European Regional Development Fund. V. Fernández-García was supported by a Predoctoral Fellowship of the Spanish Ministry of Education, Culture 
and Sport (FPU14/00636). Finally, we thank the reviewers for their constructive comments.

\section{References}

Alfaro-Sánchez, R., Camarero, J.J., López-Serrano, F.R., Sánchez-Salguero, R., Moya, D., de las Heras, J., 2015. Positive coupling between growth and reproduction in young post-fire Aleppo pines depends on climate and site conditions. Int. J. Wildland Fire 24, 507-517.

Baeza, M.J., Valdecantos, A., Alloza, J.A., Vallejo, V.R., 2007. Human disturbance and environmental factors as drivers of long-term post-fire regeneration patterns in Mediterranean forests. J. Veg. Sci. 18, 243-252.

Blair, D.P., McBurney, L.M., Blanchard, W., Banks, S.C., Lindenmayer, D.B., 2016. Disturbance gradient shows logging affects plant functional groups more than fire. Ecol. Appl. 26, 2280-2301.

Bowman, D.M.J.S., Murphy, B.P., Neyland, D.L.J., Williamson, G.J., Prior, L.D., 2014. Abrupt fire regime change may cause landscape-wide loss of mature obligate seeder forests. Glob. Change Biol. 20, 1008-1015.

Brown, C.D., Johnstone, J.F., 2012. Once burned, twice shy: repeat fires reduce seed availability and alter substrate constraints on Picea mariana regeneration. Forest Ecol. Manag. 266, 34-41.

Buma, B., 2015. Disturbance interactions: characterization, prediction, and the potential for cascading effects. Ecosphere 6, 70 .

Buma, B., Wessman, C.A., 2011. Disturbance interactions can impact resilience mechanisms of forests. Ecosphere 2, 64.

Buma, B., Brown, C.D., Donato, D.C., Fontaine, J.B., Johnstone, J.F., 2013. The impacts of changing disturbance regimes on serotinous plant populations and communities. BioScience 63, 866-876

Calvo, L., Baeza, J., Marcos, E., Santana, V., Papanastasis, V.P., 2012. Post-Fire management of shrublands. In: Moreira, F., Arianoutsou, M., Corona, P., De las Heras, J. (Eds.), Post-Fire Management and Restoration of Southern European Forests, Managing Forest Ecosystems 24. Springer Science + Business Media B.V., pp. 293-319.

Calvo, L., Santalla, S., Valbuena, L., Marcos, E., Tárrega, R., Luis-Calabuig, E., 2008. Post-fire natural regeneration of a Pinus pinaster forest in NW Spain. Plant Ecol. 197, 81-90.

Calvo, L., Torres, O., Valbuena, L., Luis-Calabuig, E., 2013. Recruitment and early growth of Pinus pinaster seedlings over five years after a wildfire in NW Spain. For. Syst. 22 (3), 582-586.

Castro, J., Allen, C.D., Molina-Morales, M., Marañón-Jiménez, S., Sánchez-Miranda, , Zamora, R., 2011. Salvage logging versus the use of burnt wood as a nurse object to promote post-fire tree seedling establishment. Restor. Ecol. 19, 537-544.

D'Amato, A.W., Fraver, S., Palik, B.J., Bradford, J.B., Patty, L., 2011. Singular and interactive effects of blowdown, salvage logging, and wildfire in sub-boreal pine systems. Forest Ecol. Manag. 262, 2070-2078.

De las Heras, J., Moya, D., Vega, J.A., Daskalakou, E., Vallejo, R., Grigoriadis, N., Tsitsoni, T., Baeza, J., Valdecantos, A., Fernández, C., Espelta, J., Fernandes, P., 2012. Post-fire management of serotinous pine forests. In: Moreira, F., Arianoutsou, M., Corona, P., De las Heras, J. (Eds.), Post-Fire Management and Restoration of Southern European Forests, Managing Forest Ecosystems 24. Springer Science + Business Media B.V., pp. 121-150.

Didham, R.K., Tylianakis, J.M., Gemmell, N.J., Rand, T.A., Ewers, R.M., 2007. Interactive effects of habitat modification and species invasion on native species decline. Trends Ecol. Evol. 22, 489-496.

Doblas-Miranda, E., Alonso, R., Arnan, X., Bermejo, V., Brotons, L., De las Heras, J., Estiarte, M., Hódar, J.A., Llorens, P., Lloret, F., López-Serrano, F.R., Martínez-Vilalta, J., Moya, D., Peñuelas, J., Pino, J., Rodrigo, A., Roura-Pascual, N., Valladares, F., Vilà, M., Zamora, R., Retana, J., 2017. A review of the combination among global change factors in forests, shrublands and pastures of the Mediterranean Region: beyond drought effects. Global Planet. Change 148, 42-54.

Doblas-Miranda, E., Martínez-Vilalta, J., Lloret, F., Álvarez, A., Ávila, A., Bonet, F.J., Brotons, L., Castro, J., Curiel Yuste, J., Díaz, M., Ferrandis, P., García-Hurtado, E., Iriondo, J.M., Keenan, T.F., Latron, J., Llusià, J., Loepfe, L., Mayol, M., Moré, G., Moya, D., Peñuelas, J., Pons, X., Poyatos, R., Sardans, J., Sus, O., Vallejo, V.R., Vayreda, J., Retana, J., 2014. Reassessing global change research priorities in Mediterranean terrestrial ecosystems: how far have we come and where do we go from here?. Global Ecol. Biogeogr. 24, 25-43.

Donato, D.C., Fontaine, J.B., Campbell, J.L., 2016. Burning the legacy? Influence of wildfire reburn on dead wood dynamics in a temperate conifer forest. Ecosphere 7, e01341.

Dunn, C.J., Bailey, J.D., 2015. Modeling the direct effects of salvage logging on long-term temporal fuel dynamics in dry-mixed conifer forests. Forest Ecol. Manag. 341, 93-109.

Espelta, J.M., Verkaik, I., Eugenio, M., Lloret, F., 2008. Recurrent wildfires constrain long-term reproduction ability in Pinus halepensis Mill. Int. J. Wildland Fire 17, 579-585.

Eugenio, M., Verkaik, I., Lloret, F., Espelta, J.M., 2006. Recruitment and growth decline in Pinus halepensis populations after recurrent wildfires in Catalonia (NE Iberian Peninsula). Forest Ecol. Manag. 231, 47-54.

Fernandes, P.M., Rigolot, E., 2007. The fire ecology and management of maritime pine (Pinus pinaster Ait.). Forest Ecol. Manag. 241, 1-13.
Fernández, C., Vega, J.A., Fonturbel, T., Jiménez, E., Pérez-Gorostiaga, P., 2008. Effects of wildfire, salvage logging and slash manipulation on Pinus pinaster Ait. recruitment in Orense (NW Spain). Forest Ecol. Manag. 255, 1294-1304.

Fernández-García, V., Santamarta, M., Fernández-Manso, A., Quintano, C., Marcos, E., Calvo, L., 2018. Burn severity metrics in fire-prone pine ecosystems along a climatic gradient using Landsat imagery. Remote Sens. Environ. 206, 205-217.

Fortin, M.-J., Drapeau, P., Legendre, P., 1989. Spatial autocorrelation and sampling design in plant ecology. Vegetatio 83, 209-222.

Foster, C.N., Sato, C.F., Lindenmayer, D.B., Barton, P.S., 2016. Integrating theory into disturbance interaction experiments to better inform ecosystem management. Global Change Biol. 22, 1325-1335.

Fraver, S., Jain, T., Bradford, J.B., D'Amato, A.W., Kastendick, D., Palik, B., Shinneman, D., Stanovick, J., 2011. The efficacy of salvage logging in reducing subsequent fire severity in conifer-dominated forests of Minnesota, USA. Ecol. Appl. 21, 1895-1901.

González-De Vega, S., De las Heras, J., Moya, D., 2016. Resilience of Mediterranean terrestrial ecosystems and fire severity in semiarid areas: responses of Aleppo pine forests in the short, mid and long term. Sci. Total Environ. 573, 1171-1177.

Hernández-Serrano, A., Verdú, M., González-Martínez, S.C., Pausas, J.G., 2013. Fire structures pine serotiny at different scales. Am. J. Bot. 100, 2349-2356.

Hood, P.R., Nelson, K.N., Rhoades, C.C., Tinker, D.B., 2017. The effect of salvage logging on surface fuel loads and fuel moisture in beetle-infested lodgepole pine forests. Forest Ecol. Manag. 390, 80-88.

Hunter, Jr., M.L., 2007. Core principles for using natural disturbance regimes to inform landscape management. In: Lindenmayer, D.B., Hobbs, R.J., (Eds.), Managing and Designing Landscapes for Conservation: Moving from Perspectives to Principles, Conservation Science and Practice Series. Blackwell Publishing Ltd., pp. 408-422.

Johnstone, J.F., Allen, C.D., Franklin, J.F., Frelich, L.E., Harvey, B.J., Higuera, P.E., Mack, M.C., Meentemeyer, R.K., Metz, M.R., Perry, G.L.W., Schoennagel, T., Turner, M.G., 2016. Changing disturbance regimes, ecological memory, and forest resilience. Front. Ecol. Environ. 14, 369-378.

Keeley, J.E., e'eman, G., Fotheringham, C.J., 1999. Immaturity risk in a fire-dependent pine. J. Mediterranean Ecol. 1, 41-48.

Keith, D.A., Rodríguez, J.P., Rodríguez-Clark, K.M., Nicholson, E., Aapala, K., Alonso, A. Asmussen, M., Bachman, S., Basset, A., Barrow, E.G., Benson, J.S., Bishop, M.J., Bonifacio, R., Brooks, T.M., Burgman, M.A., Comer, P., Comín, F.A., Essl, F., Faber-Langendoen, D., Fairweather, P.G., Holdaway, R.J., Jennings, M., Kingsford, R.T., Lester R.E., Mac Nally, R., McCarthy, M.A., Moat, J., Oliveira-Miranda, M.A., Pisanu, P., Poulin, B., Regan, T.J., Riecken, U., Spalding, M.D., Zambrano-Martínez, S., 2013. Scientific foundations for an IUCN Red List of ecosystems. PLoS ONE 8 (5), e62111.

Key, C.H., 2006. Ecological and sampling constraints on defining landscape fire severity. Fire Ecol. 2, 34-59.

Keyser, T.L., Smith, F.W., Shepperd, W.D., 2009. Short-term impact of post-fire salvage logging on regeneration, hazardous fuel accumulation and understorey development in ponderosa pine forests of the Black Hills, SD, USA. Int. J. Wildland Fire 18, 451-458.

Knapp, E.E., Ritchie, M.W., 2016. Response of understory vegetation to salvage logging following a high-severity wildfire. Ecosphere 7, e01550.

Kuznetsova, A., Brockhoff, P.B., Christensen, R.H.B., 2016. lmerTest: Tests in Linear Mixed Effects Models. R package version 2.0-32. Available at < https://CRAN.R-project.org/ package $=$ lmerTest $>$

Leverkus, A.B., Lorite, J., Navarro, F.B., Sánchez-Cañete, E.P., Castro, J., 2014. Post-fire salvage logging alters species composition and reduces cover, richness, and diversity in Mediterranean plant communities. J. Environ. Manage. 133, 323-331.

Lindenmayer, D., 2016. Interactions between forest resource management and landscape structure. Curr. Landscape Ecol. Reports 1, 10-18.

Lindenmayer, D.B., Noss, R.F., 2006. Salvage logging, ecosystem processes, and biodiversity conservation. Conserv. Biol. 20, 949-958.

Lindenmayer, D., Messier, C., Sato, C., 2016. Avoiding ecosystem collapse in managed forest ecosystems. Front. Ecol. Environ. 14, 561-568.

Lindenmayer, D., Thorn, S., Banks, S., 2017. Please do not disturb ecosystems further. Nat. Ecol. Evol. 1, 0031

Madrigal, J., Hernando, C., Martínez, E., Guijarro, M., Díez, C., 2005. Regeneración post-incendio de Pinus pinaster Ait. en la Sierra de Guadarrama (Sistema Central, España): modelos descriptivos de los factores influyentes en la densidad inicial y la supervivencia. Investigación Agraria: Sistemas y Recursos Forestales 14, 36-51.

Malvar, M.C., Silva, F.C., Prats, S.A., Vieira, D.C.S., Coelho, C.O.A., Keizer, J.J., 2017. Short-term effects of post-fire salvage logging on runoff and soil erosion. Forest Ecol. Manag. 400, 555-567.

Mandle, L., Ticktin, T., 2012. Interactions among fire, grazing, harvest and abiotic conditions shape palm demographic responses to disturbance. J. Ecol. 100, 997-1008.

Mandle, L., Ticktin, T., Zuidema, P.A., 2015. Resilience of palm populations to disturbance is determined by interactive effects of fire, herbivory and harvest. J. Ecol. 103, 1032-1043.

Marañón-Jiménez, S., Castro, J., 2013. Effect of decomposing post-fire coarse woody debris on soil fertility and nutrient availability in a Mediterranean ecosystem. Biogeochemistry $112,519-535$.

Marañón-Jiménez, S., Castro, J., Querejeta, J.I., Fernández-Ondoño, E., Allen, C.D., 2013. Post-fire wood management alters water stress, growth, and performance of pine regeneration in a Mediterranean ecosystem. Forest Ecol. Manag. 308, 231-239.

Martínez-Sánchez, J.J., Ferrandis, P., De las Heras, J., Herranz, J.M., 1999. Effect of burnt wood removal on the natural regeneration of Pinus halepensis after fire in a pine forest in Tus valley (SE Spain). Forest Ecol. Manag. 123, 1-10. 
A. Taboada et al.

Forest Ecology and Management $x x x$ (2018) $x x x-x x x$

Marzano, R., Garbarino, M., Marcolin, E., Pividori, M., Lingua, E., 2013. Deadwood anisotropic facilitation on seedling establishment after a stand-replacing wildfire in Aosta Valley (NW Italy). Ecol. Eng. 51, 117-122.

Moreira, F., Viedma, O., Arianoutsou, M., Curt, T., Koutsias, N., Rigolot, E., Barbati, A., Corona, P., Vaz, P., Xanthopoulos, G., Mouillot, F., Bilgili, E., 2011. Landscape-wildfire interactions in southern Europe: implications for landscape management. J. Environ. Manage. 92, 2389-2402.

Moya, D., de las Heras, J., López-Serrano, F.R., Ferrandis, P., 2015. Post-fire seedling recruitment and morpho-ecophysiological responses to induced drought and salvage logging in Pinus halepensis Mill. stands. Forests 6, 1858-1877.

Paula, S., Arianoutsou, M., Kazanis, D., Tavsanoglu, , Lloret, F., Buhk, C., Ojeda, F., Luna, B., Moreno, J.M., Rodrigo, A., Espelta, J.M., Palacio, S., Fernández-Santos, B., Fernandes, P.M., Pausas, J.G., 2009. Fire-related traits for plant species of the Mediterranean Basin. Ecology 90, 1420.

Pausas, J.G., Fernández-Muñoz, S., 2012. Fire regime changes in the Western Mediterranean Basin: from fuel-limited to drought-driven fire regime. Climatic Change 110, $215-226$

Pausas, J.G., Keeley, J.E., 2014. Evolutionary ecology of resprouting and seeding in fire-prone ecosystems. New Phytol. 204, 55-65.

Pausas, J.G., Vallejo, V.R., 1999. The role of fire in European Mediterranean ecosystems. In: Chuvieco, E. (Ed.), Remote Sensing of Large Wildfires in the European Mediterranean Basin (Ed.), Springer-Verlag, Berlin, pp. 3-16.

Pausas, J.G., Llovet, J., Rodrigo, A., Vallejo, R., 2008. Are wildfires a disaster in the Mediterranean basin? A review. Int. J. Wildland Fire 17, 713-723.

Pinheiro, J., Bates, D., DebRoy, S., Sarkar, D., R Core Team, 2016. nlme: Linear and Nonlinear Mixed Effects Models. R package version 3.1-128, <URL: http://CRAN. R-project.org $/$ package $=$ nlme $>$.

Quintano, C., Fernández-Manso, A., Roberts, D.A., 2017. Burn severity mapping from Landsat MESMA fraction images and land surface temperature. Remote Sens. Environ. 190, 83-95.

Quintano, C., Fernández-Manso, A., Calvo, L., Marcos, E., Valbuena, L., 2015. Land surface temperature as potential indicator of burn severity in forest Mediterranean ecosystems. Int. J. Appl. Earth Obs. 36, 1-12.

Core Team, R., 2016. R: A Language and Environment for Statistical Computing. URL Available at $<\mathrm{R}$ Foundation for Statistical Computing, Vienna, Austria, $>$.

Retana, J., Espelta, J.M., Habrouk, A., Ordóñez, J.L., de Solà-Morales, F., 2002. Regeneration patterns of three Mediterranean pines and forest changes after a large wildfire in northeastern Spain. Ecoscience 9, 89-97.
Rodrigo, A., Retana, J., Picó, F.X., 2004. Direct regeneration is not the only response of Mediterranean forests to large fires. Ecology 85, 716-729.

Rodríguez, R.J., Serrada, R., Lucas, J.A., Alejano, R., Del Río, M., Torres, E., Cantero, A., 2008. Selvicultura de Pinus pinaster Ait. subsp. mesogeensis Fieschi \& Gaussen. In: Serrada, R., Montero, G., Reque Kilchenmann, J.A. (Eds.), Compendio de Selvicultura aplicada en España. Instituto Nacional de Investigación y Tecnología Agraria y Alimentaria (INIA), Madrid, pp. 399-430.

Rodríguez-García, E., Juez, L., Bravo, F., 2010. Environmental influences on post-harvest natural regeneration of Pinus pinaster Ait. in Mediterranean forest stands submitted to the seed-tree selection method. Eur. J. For. Res. 129, pp. 1119-1128.

Santamaría, J.E., 2015. El pino pinaster de la Sierra del Teleno. Historia, ordenación, crecimiento y producción. $\mathrm{PhD}$ thesis, University of Léon, Spain.

Taboada, A., Tárrega, R., Marcos, E., Valbuena, L., Suárez-Seoane, S., Calvo, L., 2017. Fire recurrence and emergency post-fire management influence seedling recruitment and growth by altering plant interactions in fire-prone ecosystems. Forest Ecol. Manag. $402,63-75$.

Tapias, R., Climent, J., Pardos, J.A., Gil, L., 2004. Life histories of Mediterranean pines. Plant Ecol. 171, 53-68.

Tapias, R., Gil, L., Fuentes-Utrilla, P., Pardos, J.A., 2001. Canopy seed banks in Mediterranean pines of southeastern Spain: a comparison between Pinus halepensis Mill., Pinus pinaster Ait., Pinus nigra Arn. and Pinus pinea L. J. Ecol. 89, 629-638.

Thom, D., Seidl, R., 2016. Natural disturbance impacts on ecosystem services and biodiversity in temperate and boreal forests. Biol. Rev. 91, 760-781.

Trumbore, S., Brando, P., Hartmann, H., 2015. Forest health and global change. Science 349, 814-818.

Turetsky, M.R., Baltzer, J.L., Johnstone, J.F., Mack, M.C., McCann, K., Schuur, E.A.G., 2017. Losing legacies, ecological release, and transient responses: key challenges for the future of northern ecosystem science. Ecosystems 20, 23-30.

Turner, M.G., 2010. Disturbance and landscape dynamics in a changing world. Ecology 91, 2833-2849.

Vacchiano, G., Stanchi, S., Marinari, G., Ascoli, D., Zanini, E., Motta, R., 2014. Fire severity, residuals and soil legacies affect regeneration of Scots pine in the Southern Alps. Sci. Total Environ. 472, 778-788.

Venables, W.N., Ripley, B.D., 2002. Modern Applied Statistics with S, fourth ed. Springer, New York.

10 